\title{
STABILITY OF SOYBEAN YIELD THROUGH DIFFERENT SOWING PERIODS ${ }^{1}$
}

\author{
WILMAR FERREIRA LIMA², JOSÉ FRANCISCO FERRAZ DE TOLEDO³, \\ CARLOS ALBERTO ARRABAL ARIAS ${ }^{3}$ and MARCELO FERNANDES DE OLIVEIRA ${ }^{4}$
}

\begin{abstract}
Soybean yield is highly affected by sowing period and there are significant productivity losses when sowings are done outward a relatively restricted period in many regions of Brazil. Breeding cultivars less sensitive to photoperiod and to temperature variations is desirable for adaptation to wider sowing period and wider latitude range and also make irrigated soybean cultivation possible during the fall-winter seasons in frost free regions. The possibility of selecting high yielding and stable lines for yield during various sowing periods was studied by analyzing the behavior of 100 non-selected advanced lines $\left(\mathrm{F}_{9}\right.$ and $\left.\mathrm{F}_{10}\right)$, from each one of all possible biparental crosses involving the genotypes BR85-29009, OCEPAR 8, FT-2, and BR-13. Experiments were set up in a completely randomized design with single-plant hill plots and received supplementary irrigation. Sowing was on Sept 27, Oct 20, Nov 17, and Dec 17 in 1993/94 and Sept 20, Oct 20, Nov 17, and Dec 14 in 1994/95 at Londrina, PR, Brazil. Procedures of regression analysis and minimum variance among planting date means were efficient for selecting stable lines during the four sowing seasons. It was possible to select stable and high yielding genotypes through the four sowing periods in all the crosses. No specific cross was clearly better to produce a greater number of stable genotypes.
\end{abstract}

Index terms: Glycine max, cultivars, genotypes, progeny, photoperiodicity, temperature, yields, productivity.

\section{ESTABILIDADE DE PRODUÇÃO DA SOJA EM DIFERENTES ÉPOCAS DE SEMEADURA}

RESUMO - A produtividade da soja é muito influenciada pela época de semeadura, ocorrendo perdas significativas na produtividade quando as semeaduras são realizadas fora de um período relativamente restrito em muitas regiões do Brasil. A criação de cultivares menos sensíveis à variação do fotoperíodo e da temperatura, além de possibilitar a ampliação do período de semeadura, permite o cultivo dessas cultivares numa faixa mais ampla de latitude e a viabilização do cultivo de soja irrigada, durante o outono-inverno, em regiões isentas de geadas. Para estudar a possibilidade de selecionar linhagens produtivas e estáveis às épocas de semeadura, 100 linhagens $\left(\mathrm{F}_{9}\right.$ e $\left.\mathrm{F}_{10}\right)$ não-selecionadas, derivadas de cada um dos possíveis cruzamentos entre os genótipos BR85-29009, OCEPAR-8, FT-2 e BR-13, foram semeadas em experimentos irrigados instalados segundo esquema em covas, sob um delineamento inteiramente casualizado. As datas de semeadura no campo foram 27/09, 20/10, 17/11 e 17/12, em 1993/94 e 20/09, 20/10 17/11 e 14/12, em 1994/95, em Londrina, PR. Métodos de análise de regressão e de variância mínima entre médias de épocas de semeadura foram eficientes para selecionar linhagens estáveis às épocas de semeadura. Foi possível selecionar genótipos estáveis às quatro épocas de semeadura, em todos os cruzamentos, e não foi observada superioridade de um cruzamento específico.

Termos para indexação: Glycine max, cultivares, genótipos, progênie, fotoperiodicidade, temperatura, rendimento, produtividade.

\footnotetext{
${ }^{1}$ Accepted for publication on January 24, 2000.

2 Agronomist, M.Sc., Caixa Postal 231, CEP 86051-970 Londrina, PR, Brazil.

${ }^{3}$ Agronomist, Ph.D., Embrapa-Centro Nacional de Pesquisa de Soja (CNPSo), Caixa Postal 231, CEP 86001-970 Londrina, PR, Brazil. E-mail: toledo@cnpso.embrapa.br, arias@cnpso.embrapa.br

${ }^{4}$ Agronomist, M.Sc., Embrapa-CNPSo.

E-mail: marcelo@cnpso.embrapa.br
}

\section{INTRODUCTION}

Soybean (Glycine max (L.) Merrill) is a short-day plant that originated from latitudes of about $45^{\circ} \mathrm{N}$ and has been cultivated for relatively few years in the tropical and equatorial regions. The cultivars currently available are heavily influenced by the sowing period. In the state of Paraná, located between 
$23^{\circ}$ and $27^{\circ}$ south, the ideal sowing period is from October 20 to November 15. Both earlier and later sowings result in heavy losses in yield ranging from $10 \%$ to $40 \%$ (Carraro et al., 1984; Semeadura..., 1994). In the majority of the Savannah regions, sowing at the end of December and January may cause a yield reduction of $30 \%$ or higher compared with sowing in November (Urben Filho \& Souza, 1993; Embrapa, 1994). Sowing out of season causes losses for many producers, who, due to climatic reasons or machinery limitations, can not sow during the ideal period.

Cultivars with a long juvenile period under shortday conditions (Hartwig \& Kiihl, 1979; Kiihl \& Garcia, 1989) are used in lower latitude areas in Brazil, where the number of daylight hours is insufficient for normal development of short day cultivars. These materials, however, do not totally solve the problem as they are also responsive to the sowing period. Genetic control of late flowering under short day conditions (long juvenile period) may involve either important recessive genes (Hartwig \& Kiihl, 1979) or are controlled by quantitative genes (Toledo et al., 1994). Genetically balanced, less sensitive materials to sowing period can be obtained with use of quantitative gene breeding.

It is not so much important to have soybean cultivars with stable yield during various sowing periods in countries with latitudes higher than $30^{\circ}$. Seasons are well defined, and crops have to be sown during a restricted period because the climatic conditions outside this period (frosts, for example), drastically affect crops. Therefore, breeding for stability has been carried out mostly in Brazil, where soybean is cultivated in latitudes lower than $30^{\circ}$.

The objective of this study was to analyze the possibility of selecting high yielding and stable soybean inbred lines through various sowing periods. Development of lines or cultivars less sensitive to photoperiod and temperature variation would allow the lengthening of the sowing period, cultivation of these cultivars in a wider latitude range and cropping of irrigated soybean during the fall-winter, in frost free regions.

\section{MATERIAL AND METHODS}

Four soybean genotypes were selected for this study: 'BR85-29009' [União (6) x Lo76-1763, Lo 76-1763 was selected from 'Industrial']; 'OCEPAR 8' (late mutant of 'Paraná', with late flowering under short-day conditions, i.e. longer juvenile period); 'FT-2' (selected from 'IAS 5') and 'BR-13' [Bragg (4) x Santa Rosa]. The BR 85-29009 line and OCEPAR 8, FT-2, and BR-13 have maturity of $124,122,128$ and 124 days, respectively, when sown in November in Londrina, $23^{\circ} 23^{\prime}$ south. However, their responses vary considerably to differences in day length: BR 85-29009, FT-2 and BR-13 genotypes have a classic response to different day lengths, according to Gregan \& Hartwig (1984), Hinson (1989), Kiihl \& Garcia (1989), but they have different genetic constitutions (Embrapa, 1994), and OCEPAR 8 has the long juvenile trait, delaying the flowering under short-day conditions when compared to the classic genotypes. Six possible combinations were produced among the four parents, as well as their reciprocals, and 100 random lines were obtained without selection from each cross, including the reciprocals. The single seed descent (SSD) method was used to increase homozygosis and obtain the random inbred lines (RIL).

The lines and the parents were sown on four dates: September 27, October 20, November 17, and December 17, 1993 ( $F_{9}$ plants) and September 20, October 20, November 17, and December 14, 1994 ( $\mathrm{F}_{10}$ plants), in Londrina, Paraná, Brazil. The experiment, including the parents and all the inbred lines derived from the six biparental crosses, was set up in a completely randomized design with single-plant hill plots. Plants were spaced $20 \mathrm{~cm}$ within row and $1.5 \mathrm{~m}$ between rows. Between these experimental rows, two border rows of plants spaced $5 \mathrm{~cm}$ were sown with remnant seeds. The final row spacing was $50 \mathrm{~cm}$ to guarantee plant population and competition, similar to that of a regular soybean crop (about 250,000 to 300,000 plants/ha). The two border rows also facilitate the access of workers during the evaluations. The replication number was 50 plots for each parent and four plots for each of the 100 lines, for each sowing period. Field conditions were kept close to optimum for normal plant development, including supplementary irrigation. Plants were individually identified for harvesting and dried naturally in half-closed sheds for later shattering and grain yield evaluation.

Before studying the response of genotypes or inbred lines to the differences among environmental conditions, mainly photoperiod and temperature, it is important to know the relative magnitude of year, sowing date and the interaction effects between them. Thus, an analysis of variance was carried out, using the following mathematical model:

$Y_{i j k}=\mu+A_{i}+E_{j}+(A E)_{i j}+\varepsilon_{k}(i j)$

where, 
$\mathrm{Y}_{\mathrm{ijk}}$ : effect of the $\mathrm{i}^{\text {th }}$ year, $\mathrm{j}^{\text {th }}$ period and $\mathrm{k}^{\text {th }}$ replication; $\mu$ : general mean;

$A_{i}$ : effect of the $i^{\text {th }}$ year ( $i=1$ to 2 );

$E_{j}$ : effect of the $j^{\text {th }}$ sowing date $(j=1$ to 4$)$;

$(\mathrm{AE})_{\mathrm{ij}}$ : interaction between the $\mathrm{i}^{\text {th }}$ year and $\mathrm{j}^{\text {th }}$ sowing; $\varepsilon_{\mathrm{k}}(\mathrm{ij})$ : experimental error.

Stability parameters were estimated according to Eberhart \& Russell (1966). The parameters evaluated by this method include grain yield mean of each genotype; regression coefficient (b), which measures sensitivity or responsiveness of genotypes to environmental changes; $\left(\mathrm{R}^{2}\right)$ determination coefficient and deviation of the linear regression $\left(\sigma_{d}^{2}\right)$, which is defined as the squared mean of the distances of the points of the calculated regression line, estimated by $\left[\sigma_{d}^{2}=(\mathrm{MSDI}-\mathrm{MSE}) / \mathrm{r}\right]$, where $\mathrm{MSD}_{\mathrm{i}}$ is the mean square of the regression deviations, obtained for each genotype, MSE is the mean square of the residue, and $r$ is the number of replications for each sowing date.

Another method, named minimum variance method, was also tested in this work. It consists of calculating the variance among sowing date means and residual variance, based on an analysis of variance carried out for each genotype and each cross, with a model including only the sowing period effect. Thus, the mean square of the sowings is equal to the variance among the means of the sowing dates, and the residual mean square is equivalent to the residual variance.

\section{RESULTS AND DISCUSSION}

Some cross combinations showed significant reciprocal effects for grain yield, but because our objective was to study the behavior of inbred lines derived from each cross and its reciprocal as a unit, the lines derived from the reciprocal crosses were pooled.

Comparison of the yield means of the 100 RILs of each of the six crosses during the two years, showed that they yielded less in September and December and yielded more in October and November (Table 1). Similar results were reported by Carraro et al. (1984), and is a consequence of inadequate photoperiod and temperature for normal soybean development outside the ideal period (late October until mid November). The mean response of the studied materials was expected, since three of the four parents have traditional photoperiod responses. Photoperiod responses of the parents suggested that the ideal non-responsive genotype should not be fre- quently found among the advanced inbred lines derived from the crosses used in this study. Thus, an adequate methodology should be used to help the breeder screen genotypes for selection. All crosses showed that the yield means of the four periods in the 1993/94 agricultural year were greater than those in 1994/95. Considering that the experiments were irrigated and maintained under similar growing conditions (soil preparation, fertilization) this difference can mainly be attributed to the temperature effect. The monthly temperature means collected in the evaluated environments showed that temperatures from September to April of 1993/94 were predominantly lower than in the same period of 1994/95. Along with the observed temperature differences, other environmental stresses may have diminished soybean yield in 1994/95. This, however, is not likely to have occurred because of the well managed fertility and insect and disease control in the experiments.

The methodology of Eberhart \& Russell (1966) was applied to the data set, producing the four parameters summarized inTable 2. Among these, the responsiveness (b) parameter is positively correlated with the determination coefficient $\left(\mathrm{R}^{2}\right)$ for the linear regression model. Therefore, lower values of responsiveness (b), or absence of linear regression, decreases the $\mathrm{R}^{2}$ value. According to the criteria used, genotypes must have $\mathrm{b}<1$ to be selected as non-responsive to different sowing dates and, consequently, they showed lower $\mathrm{R}^{2}$ values. Comparison of the means, responsiveness (b), and predictability $\left(\sigma_{d}^{2}\right)$ parameters of the lines derived from the six crosses allowed the identification of lines that had higher yields and lower responsiveness (b lower than 1 ) and predictability ( $\sigma_{d}^{2}$ not significant or with relative low values) than the best parent. This shows that it is possible to select higher yielding inbred lines with different sensitivity levels to the sowing dates. For example, line 76 from the cross between BR 85-29009 and FT-2, line 64 from the cross BR85-29009 x BR-13, and line 14 from the cross BR-13 x OCEPAR 8, among others, had higher yields and less sensitivity. This proportion of less sensitive lines to environmental variations (photoperiod and temperature) is sufficient for success in the selection of more stable genotypes for these different sowing dates. Also, line 64 from the cross 
BR85-2909 x BR-13, which showed significant regression deviations indicating unpredictable behavior, should be selected since the size of this deviation was small in practice $( \pm 2.84 \mathrm{~g})$.

The parameters related to the minimum variance among sowing date means method are summarized in Table 3. Higher yielding genotypes with lower values for the variance among sowing date means (VM) and for the residual variance (RV) were ideal. Genotypes with small VM values are more stable across the different sowing dates. RV shows the quality of each sowing date mean estimation, increasing when the replication data were far from their mean. All crosses produced superior lines compared with their parents. For example, lines 8, 64, 41, and 53, which originated from the crosses BR85-29009 $\mathrm{x}$ FT-2, BR85-29009 x BR-13, FT-2 x BR-13 and FT-2 x OCEPAR 8, respectively, presented higher yield means with relatively small VMs than their parental genotypes, and can be used in breeding programs as stability sources across the diverse sowing dates. The inbred lines' residual variances were relatively high because of the small number of plots used.
Although several lines have been found displaying superior characteristics to the parents, a stable genotype with high yield across different sowing periods demands greater effort from the breeder, who will have to deal with larger samples and/or recombine selected lines, and proceed with new selection cycles. Greater, faster genetic gains may be obtained through selecting stable materials during more restricted sowing periods, for example from October to December, which are more frequent than stable materials during all four sowing periods. Therefore, to solve the farmers' problem of lost productivity because of a delay in the sowing season, it is suggested to select materials sown from November to January, instead of September to December, as was done in this study.

The two methodologies were generally efficient in selecting stable lines for the four sowing seasons. For example, line 64 from cross BR85-29009x BR-13 (Fig. 1) and line 14 from cross BR85-29009 x OCEPAR 8 (Fig. 2), are more desirable than line BR85-29009, which was considered the most stable among the four parents studied. The stability of line

TABLE 1. Mean grain yield (g/plant) of 100 advanced inbred lines from six biparental crosses for four sowing dates (September, October, November, and December), assessed in the years 1993/94 and 1994/95 in Londrina, PR'.

\begin{tabular}{lccccc}
\hline Cross & Sept & Oct & Nov & Dec & Mean \\
\hline & & & $1993 / 94$ & & \\
BR85-29009 x FT-2 & $29.42 \pm 0.66 \mathrm{~d}$ & $42.39 \pm 0.81 \mathrm{a}$ & $39.18^{ \pm} 0.82 \mathrm{~b}$ & $35.45^{ \pm} 0.76 \mathrm{c}$ & $36.62^{ \pm} 0.40 \mathrm{~A}$ \\
BR85-29009 x BR-13 & $27.93 \pm 0.88 \mathrm{c}$ & $39.39 \pm 1.05 \mathrm{a}$ & $34.87 \pm 0.83 \mathrm{~b}$ & $33.93 \pm 0.78 \mathrm{~b}$ & $34.04^{ \pm} 0.46 \mathrm{~A}$ \\
BR85-29009 x OCEPAR 8 & $33.60^{ \pm} 1.02 \mathrm{c}$ & $51.21^{ \pm} 1.22 \mathrm{a}$ & $40.71^{ \pm} 0.97 \mathrm{~b}$ & $30.62 \pm 0.60 \mathrm{c}$ & $39.15^{ \pm} 0.55 \mathrm{~A}$ \\
FT-2 x BR-13 & $18.94 \pm 0.46 \mathrm{c}$ & $28.23 \pm 0.80 \mathrm{a}$ & $26.40 \pm 0.72 \mathrm{a}$ & $22.88 \pm 0.60 \mathrm{~b}$ & $24.11^{ \pm} 0.34 \mathrm{~A}$ \\
FT-2 x OCEPAR 8 & $29.09 \pm 0.72 \mathrm{c}$ & $42.53 \pm 0.94 \mathrm{a}$ & $32.45^{ \pm} 0.80 \mathrm{~b}$ & $24.79 \pm 0.71 \mathrm{~d}$ & $32.44^{ \pm} 0.44 \mathrm{~A}$ \\
BR-13 x OCEPAR 8 & $24.14 \pm 0.82 \mathrm{c}$ & $38.29 \pm 1.02 \mathrm{a}$ & $30.74^{ \pm} 0.87 \mathrm{~b}$ & $23.82 \pm 0.73 \mathrm{c}$ & $29.37 \pm 0.46 \mathrm{~A}$ \\
\hline & & & $1994 / 95$ & & \\
BR85-29009 x FT-2 & $21.82 \pm 0.53 \mathrm{~b}$ & $35.66 \pm 0.81 \mathrm{a}$ & $34.92 \pm 0.74 \mathrm{a}$ & $22.05 \pm 0.50 \mathrm{~b}$ & $28.63 \pm 0.37 \mathrm{~A}$ \\
BR85-29009 x BR-13 & $21.90 \pm 0.71 \mathrm{~b}$ & $33.16^{ \pm} 1.10 \mathrm{a}$ & $31.73 \pm 0.74 \mathrm{a}$ & $17.90 \pm 0.45 \mathrm{c}$ & $26.16^{ \pm} 0.43 \mathrm{~A}$ \\
BR85-29009 x OCEPAR 8 & $28.46 \pm 0.72 \mathrm{c}$ & $46.49 \pm 1.44 \mathrm{a}$ & $33.60 \pm 0.74 \mathrm{~b}$ & $19.14 \pm 0.51 \mathrm{~d}$ & $31.89 \pm 0.52 \mathrm{~A}$ \\
FT-2 x BR-13 & $13.99 \pm 0.37 \mathrm{~d}$ & $23.12 \pm 0.66 \mathrm{~b}$ & $29.48 \pm 0.68 \mathrm{a}$ & $17.59 \pm 0.42 \mathrm{c}$ & $21.00 \pm 0.31 \mathrm{~A}$ \\
FT-2 x OCEPAR 8 & $20.80 \pm 0.59 \mathrm{~b}$ & $35.17 \pm 0.88 \mathrm{a}$ & $34.49 \pm 0.75 \mathrm{a}$ & $20.88 \pm 0.53 \mathrm{~b}$ & $27.85^{ \pm} 0.40 \mathrm{~A}$ \\
BR-13 x OCEPAR 8 & $19.20 \pm 0.66 \mathrm{~b}$ & $31.85 \pm 1.06 \mathrm{a}$ & $30.39 \pm 0.69 \mathrm{a}$ & $17.00 \pm 0.45 \mathrm{~b}$ & $24.61^{ \pm} 0.41 \mathrm{~A}$ \\
\hline
\end{tabular}

1 Means followed by the same capital letter for year means and small letters for sowing dates during the year did not differ by the $5 \%$ probability level Tukey test. 
TABLE 2. Mean, regression coefficient of the response to environmental indices (b), coefficient of determination $\left(R^{2}\right)$ and deviations from regression $\left(\sigma_{d}^{2}\right)$ of grain yield (g/plant), for 100 lines in each parental cross and some selected lines, for the years 1993/94 and 1994/95 in Londrina, PR.

\begin{tabular}{|c|c|c|c|c|}
\hline Genotype & Mean & $\mathrm{b}$ & $\mathrm{R}^{2}$ & $\sigma_{d}^{2}$ \\
\hline & \multicolumn{4}{|c|}{ BR85-29009xFT-2 } \\
\hline FT-2 & $24.99 \pm 0.56$ & $0.65^{\mathrm{ns}}$ & 0.12 & $-7.11^{\mathrm{ns}}$ \\
\hline BR85-29009 & $34.84 \pm 0.75$ & $0.97^{\mathrm{ns}}$ & 0.14 & $3.49 *$ \\
\hline Means $^{1}$ & $32.61 \pm 0.25$ & & & \\
\hline 10 & $44.78 \pm 5.11$ & $0.76^{\mathrm{ns}}$ & 0.05 & $29.43 * *$ \\
\hline 8 & $41.36 \pm 2.37$ & $0.77^{\mathrm{ns}}$ & 0.11 & $-0.94^{\mathrm{ns}}$ \\
\hline \multirow[t]{2}{*}{76} & $40.81 \pm 3.16$ & $0.45^{\mathrm{ns}}$ & 0.04 & $4.94^{\mathrm{ns}}$ \\
\hline & \multicolumn{4}{|c|}{ BR85-29009xBR-13 } \\
\hline BR-13 & $15.16 \pm 0.45$ & $0.32 *$ & 0.05 & $-11.47^{\mathrm{ns}}$ \\
\hline BR85-29009 & $34.84 \pm 0.76$ & $0.97^{\mathrm{ns}}$ & 0.14 & $3.45^{*}$ \\
\hline Means & $30.08 \pm 0.28$ & & & \\
\hline 7 & $48.53 \pm 3.51$ & $0.34 *$ & 0.01 & $29.77 * *$ \\
\hline 64 & $43.48 \pm 2.84$ & $0.06 * *$ & 0.00 & $11.74 *$ \\
\hline \multirow[t]{2}{*}{14} & $41.57 \pm 2.23$ & $0.54^{\mathrm{ns}}$ & 0.06 & $-1.31^{\mathrm{ns}}$ \\
\hline & \multicolumn{4}{|c|}{ BR85-29009xOCEPAR 8} \\
\hline OCEPAR 8 & $27.51 \pm 0.69$ & $1.24^{\mathrm{ns}}$ & 0.28 & $-11.10^{\mathrm{ns}}$ \\
\hline BR85-29009 & $34.84 \pm 0.76$ & $0.97^{\mathrm{ns}}$ & 0.14 & $-3.55^{\mathrm{ns}}$ \\
\hline Means & $35.52 \pm 0.33$ & & & \\
\hline 14 & $50.02 \pm 3.50$ & $0.90^{\mathrm{ns}}$ & 0.07 & $19.53 * *$ \\
\hline \multirow[t]{2}{*}{79} & $39.85 \pm 2.69$ & $0.83^{\mathrm{ns}}$ & 0.11 & $-1.66^{\mathrm{ns}}$ \\
\hline & \multicolumn{4}{|c|}{ FT-2xBR-13 } \\
\hline BR-13 & $15.16 \pm 0.45$ & $0.32 *$ & 0.05 & $-3.34^{\mathrm{ns}}$ \\
\hline FT-2 & $24.99 \pm 0.56$ & $0.65^{\mathrm{ns}}$ & 0.12 & $0.97^{\mathrm{ns}}$ \\
\hline Means & $22.52 \pm 0.20$ & & & \\
\hline 41 & $36.02 \pm 2.60$ & $0.75^{\mathrm{ns}}$ & 0.09 & $12.23 * *$ \\
\hline 28 & $29.59 \pm 2.32$ & $0.67^{\mathrm{ns}}$ & 0.09 & $7.22 *$ \\
\hline \multirow[t]{2}{*}{78} & $29.50 \pm 2.94$ & $0.34 *$ & 0.02 & $21.74 * *$ \\
\hline & \multicolumn{4}{|c|}{ FT-2xOCEPAR 8} \\
\hline FT-2 & $24.99 \pm 0.56$ & $0.65^{\mathrm{ns}}$ & 0.12 & $-5.97^{\mathrm{ns}}$ \\
\hline OCEPAR 8 & $27.51 \pm 0.69$ & $1.24^{\mathrm{ns}}$ & 0.28 & $-2.91^{\mathrm{ns}}$ \\
\hline Means & $30.11 \pm 0.25$ & & & \\
\hline 53 & $44.24 \pm 3.24$ & $0.84^{\mathrm{ns}}$ & 0.08 & $17.03 * *$ \\
\hline 96 & $41.02 \pm 3.13$ & $0.82^{\mathrm{ns}}$ & 0.08 & $16.89 *$ \\
\hline \multirow[t]{2}{*}{54} & $35.55 \pm 2.86$ & $0.58^{\mathrm{ns}}$ & 0.04 & $12.98^{*}$ \\
\hline & \multicolumn{4}{|c|}{ BR-13xOCEPAR 8} \\
\hline BR-13 & $15.16 \pm 0.45$ & $0.32 *$ & 0.05 & $-8.66^{\mathrm{ns}}$ \\
\hline OCEPAR 8 & $27.51 \pm 0.69$ & $1.24^{\mathrm{ns}}$ & 0.28 & $-1.29^{\mathrm{ns}}$ \\
\hline Means & $26.93 \pm 0.27$ & & & \\
\hline 49 & $39.70 \pm 2.47$ & $0.86^{\mathrm{ns}}$ & 0.14 & $2.80^{\mathrm{ns}}$ \\
\hline 10 & $39.62 \pm 3.73$ & $0.45^{\mathrm{ns}}$ & 0.02 & $35.28 * *$ \\
\hline 14 & $37.04 \pm 2.60$ & $0.36^{*}$ & 0.02 & $6.28^{\mathrm{ns}}$ \\
\hline
\end{tabular}

${ }^{1}$ Mean value of 100 inbred lines.

ns, $*$ and $* *$ Non-significant and significant at the $5 \%$ and $1 \%$ probability level by $\mathrm{F}$ test, respectively. 
TABLE 3. Mean, variance among means of sowing dates $(V M)$ and residual variance $(R V)$ for grain yield (g/plant), of 100 lines in each parental cross and some selected lines, in the years $1993 / 94$ and $1994 / 95$ in Londrina, PR.

\begin{tabular}{|c|c|c|c|}
\hline Genotype & Mean & $\mathrm{VM}$ & RV \\
\hline & \multicolumn{3}{|c|}{ BR85-29009xFT-2 } \\
\hline FT-2 & $24.99 \pm 0.56$ & 21.92 & 120.78 \\
\hline BR85-29009 & $34.84 \pm 0.75$ & 41.82 & 222.50 \\
\hline Means $^{1}$ & $32.61 \pm 0.25$ & & \\
\hline 10 & $44.78 \pm 5.11$ & 85.46 & 391.85 \\
\hline 30 & $42.46 \pm 2.93$ & 88.99 & 275.29 \\
\hline \multirow[t]{2}{*}{8} & $41.36 \pm 2.37$ & 26.19 & 174.65 \\
\hline & \multicolumn{3}{|c|}{ BR85-29009xBR-13 } \\
\hline BR-13 & $15.16 \pm 0.45$ & 18.35 & 75.70 \\
\hline BR85-29009 & $34.84 \pm 0.76$ & 41.82 & 222.50 \\
\hline Means & $30.08 \pm 0.28$ & & \\
\hline 86 & $44.14 \pm 3.00$ & 73.91 & 287.70 \\
\hline 64 & $43.48 \pm 2.84$ & 17.64 & 249.71 \\
\hline \multirow[t]{2}{*}{14} & $41.57 \pm 2.23$ & 32.85 & 158.88 \\
\hline & \multicolumn{3}{|c|}{ BR85-29009xOCEPAR 8} \\
\hline OCEPAR 8 & $27.51 \pm 0.69$ & 76.53 & 181.68 \\
\hline BR85-29009 & $34.84 \pm 0.76$ & 41.82 & 222.50 \\
\hline Means & $35.52 \pm 0.33$ & & \\
\hline 14 & $50.02 \pm 3.50$ & 48.12 & 391.75 \\
\hline 60 & $42.10 \pm 3.99$ & 77.95 & 492.84 \\
\hline \multirow[t]{2}{*}{16} & $38.45 \pm 2.76$ & 65.86 & 244.61 \\
\hline & \multicolumn{3}{|c|}{ FT-2xBR-13 } \\
\hline BR-13 & $15.16 \pm 0.45$ & 18.35 & 75.70 \\
\hline FT-2 & $24.99 \pm 0.56$ & 21.92 & 120.78 \\
\hline Means & $22.52 \pm 0.20$ & & \\
\hline 41 & $36.02 \pm 2.60$ & 27.30 & 209.78 \\
\hline 42 & $31.25 \pm 2.60$ & 82.41 & 203.27 \\
\hline \multirow[t]{2}{*}{28} & $29.59 \pm 2.32$ & 36.11 & 167.48 \\
\hline & \multicolumn{3}{|c|}{ FT-2xOCEPAR 8} \\
\hline FT-2 & $24.99 \pm 0.56$ & 21.92 & 120.78 \\
\hline OCEPAR 8 & $27.51 \pm 0.69$ & 76.53 & 181.68 \\
\hline Means & $30.11 \pm 0.25$ & & \\
\hline 66 & $48.04 \pm 3.70$ & 90.43 & 177.00 \\
\hline 53 & $44.24 \pm 3.24$ & 31.13 & 305.12 \\
\hline \multirow[t]{2}{*}{86} & $42.41 \pm 2.81$ & 53.66 & 229.18 \\
\hline & \multicolumn{3}{|c|}{ BR-13xOCEPAR 8} \\
\hline BR-13 & $15.16 \pm 0.45$ & 18.35 & 75.70 \\
\hline OCEPAR 8 & $27.51 \pm 0.69$ & 76.53 & 181.68 \\
\hline Means & $26.93 \pm 0.27$ & & \\
\hline 34 & $46.39 \pm 2.98$ & 61.40 & 266.12 \\
\hline 96 & $40.74 \pm 2.54$ & 86.48 & 200.74 \\
\hline 10 & $39.62 \pm 3.73$ & 46.39 & 416.30 \\
\hline
\end{tabular}

${ }^{1}$ Mean value of 100 inbred lines.
64 was a result of its relatively high yields in December, November and September coupled with average performance in October (Fig. 1). Line 14 was not selected for stability, because it showed similar sowing date responsiveness compared to the standard BR85-29009 (Fig. 2), in spite of its higher grain yield mean. The relative performance of line 14 during the different sowing dates was similar to the average of line 64 in October and relatively superior in the other sowing dates. It was found that some lines selected by the Eberhart \& Russell (1966) method, for example line 7 from cross BR85-29009 x BR-13 (Fig. 1) and line 79 from cross BR85-29009 x OCEPAR 8 (Fig. 2), were not desirable. The b value of line 7 was less that of BR85-29009, but visually (Fig. 1) it seemed to vary greatly, with high yield means in September and October and intermediary means in November and December. Similar performance was shown by line 79 (Fig. 2). This happened because the regression coefficient $b$ (one of the stability parameters) is estimated in relation to the environmental index and $b$ values lower than 1 only indicates that these lines respond differently to the sowing dates in relation to the general mean of the materials, which is used to calculate the environmental index. So, it is possible to find a line with a $b$ value close to zero, showing some response to the sowing date that differ from that given by the environmental index. In spite of this fact, the lines selected by the Eberhart \& Russell (1966) method proved to be superior in relation to the standard BR85-29009.

The mean yield of each line at each sowing date helped screening more stable lines for these four sowing dates.

It is important to emphasize that the 100 lines derived from each cross, which were used to represent the cross potential to produce stable lines in the four sowing dates, were not selected (they were obtained randomly by the SSD method) because they were developed for other purposes. Therefore, if very weak, short and poor performing lines could be eliminated during inbreeding, the increase in the frequency of superior lines in previous generations could result in better materials among the 100 lines used and increase the chances of obtaining the desirable inbreds. 

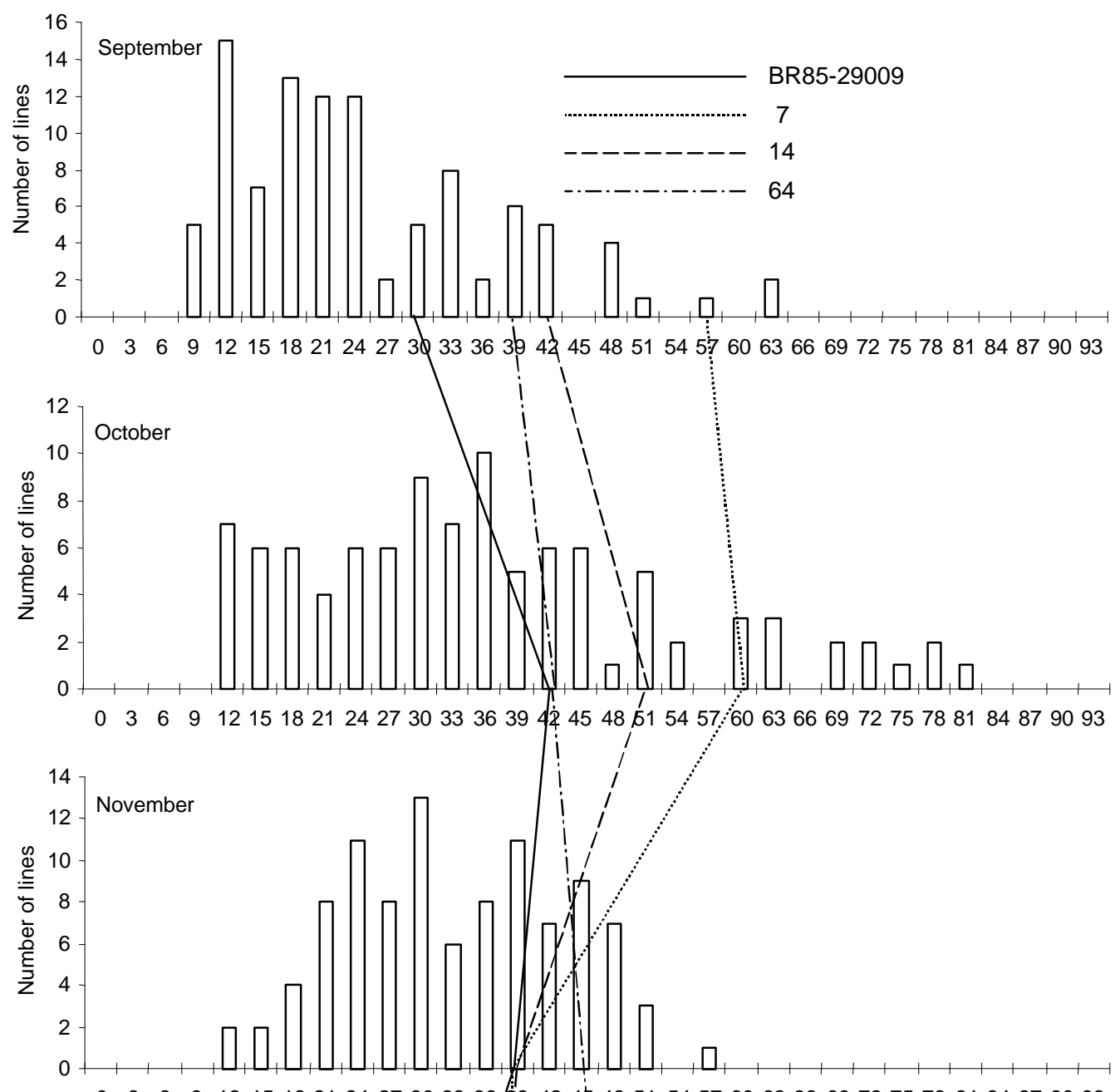

$0 \quad 3 \quad 6 \quad 9121518212427303336 \quad 94924548515457606366697275788184879093$

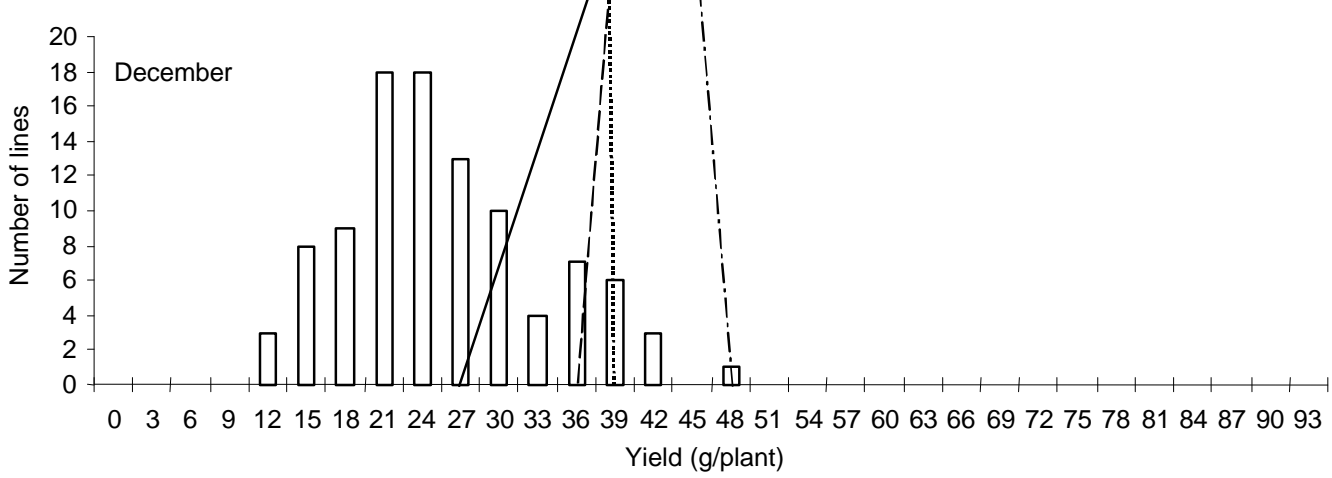

FIG. 1. Distribution frequency of the inbred lines, behavior of some selected lines and of the best parent, obtained in cross BR85-29009 $\times$ BR-13 in the four sowing dates, for the grain yield (g/plant). Average of the two years. 

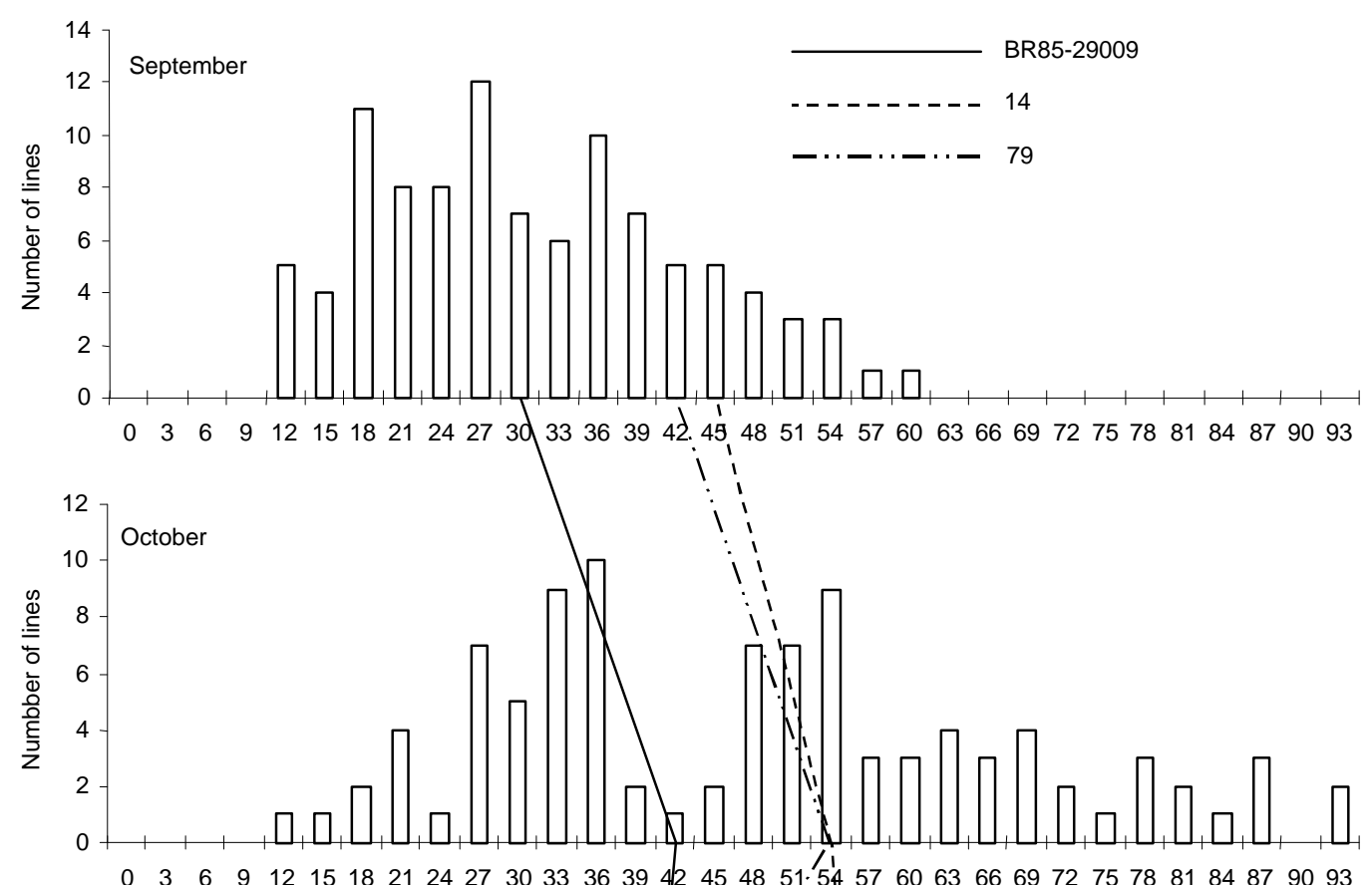

1

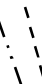

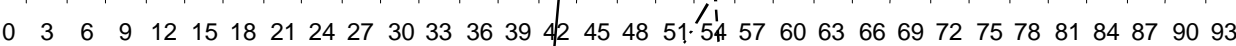

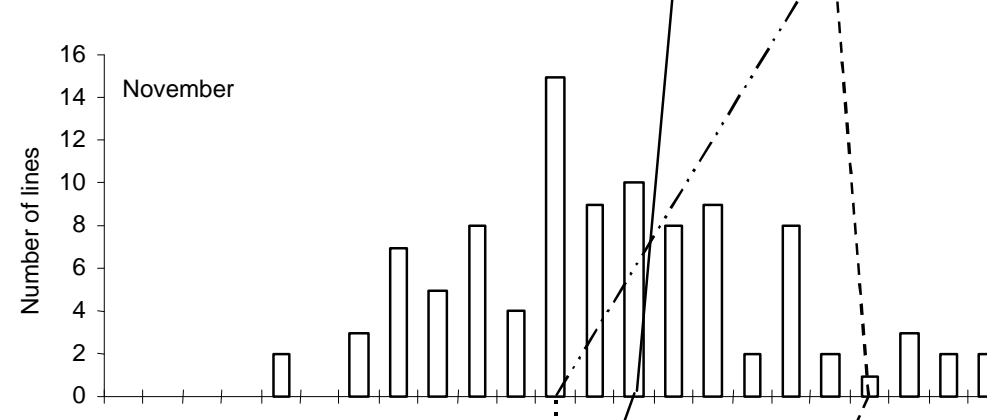

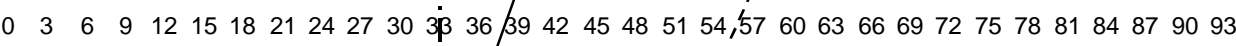

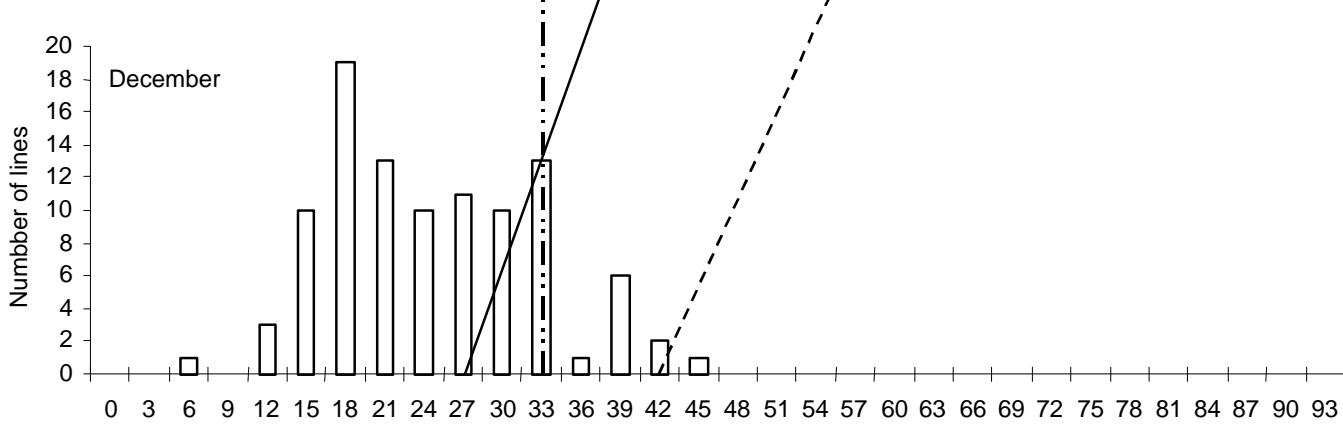

Yield (g/plant)

FIG. 2. Distribution frequency of the inbred lines, behavior of some selected lines and of the best parent, obtained in cross BR85-29009 $x$ OCEPAR 8 in the four sowing periods, for the grain yield (g/plant). Average of the two years. 


\section{CONCLUSIONS}

1. The characteristic curve of soybean yield decreasing from early/normal (September, October and November) to late (December) sowings can be changed by selection of adapted germplasm.

2. It is possible to select stable and high yielding soybean genotypes for a long sowing period, for example from September to December.

3. Regression analysis and minimum variance among plant date means can successfully be applied in selecting stable inbred lines for different sowing dates.

4. Differences in cross potential to generate superior high yielding and stable genotypes exist, but no cross was clearly superior to the other; large inbred lines samples are needed for successful selection to take place.

\section{ACKNOWLEDGMENTS}

To CAPES and CNPq for financial support.

\section{REFERENCES}

CARRARO, I.M.; SEDIYAMA, C.S.; ROCHA, A.; BAIRRÃO, J.F.M. Efeito da época de semeadura sobre altura e rendimento de doze cultivares de soja em Cascavel (PR). In: SEMINÁRIO NACIONAL DE PESQUISA DE SOJA, 3., 1984, Campinas. Anais. Londrina : Embrapa-CNPSo, 1984. p.70-81.

EBERHART, S.A.; RUSSELL, W.A. Stability parameters for comparing varieties. Crop Science, Madison, v.6, p.36-40, 1966.

EMBRAPA. Centro Nacional de Pesquisa de Soja (Londrina, PR). Época de semeadura. In:
Recomendações técnicas para a cultura da soja na região central do Brasil: 1994/95. Londrina, 1994. p.65-66. (Embrapa-CNPSo. Documentos, 77).

GREGAN, P.B.; HARTWIG, E.E. Characterization of flowering response to photoperiod in diverse soybean genotypes. Crop Science, Madison, v.24, p.659-662, 1984.

HARTWIG, E.E.; KIIHL, R.A.S. Identification and utilization of a delayed flowering character in soybeans for short-day conditions. Field Crops Research, Amsterdam, v.2, p.145-151, 1979.

HINSON, K. The use of a long juvenile trait in cultivar development. In: CONFERENCIA MUNDIAL DE INVESTIGACION EN SOJA, 4., 1989, Buenos Aires. Anales. Buenos Aires : AASoja, 1989. p.983987.

KIIHL, R.A.S.; GARCIA, A. The use of the long-juvenile trait in breeding cultivars. In: CONFERENCIA MUNDIAL DE INVESTIGACION EN SOJA, 4., 1989, Buenos Aires. Anales. Buenos Aires : AASoja, 1989. p.994-1000.

SEMEADURA após a época convencional. In: OCEPAR (Cascavel, PR). Recomendações técnicas para a cultura da soja no Paraná 1994/1995. Cascavel : OCEPAR/Embrapa-CNPSo, 1994. p.93.

TOLEDO, J.F.F.; TRILLER, C.; DONATO, L.T.; OLIVEIRA, M.F.; TSUTIDA, A.C. Genetic control of flowering in determinate soybean genotypes under diverse photoperiods. Revista Brasileira de Genética, Ribeirão Preto, v.17, n.2, p.187-195, 1994.

URBEN FILHO, G.; SOUZA, P.I.M. Manejo da cultura da soja sob cerrado: época, densidade e profundidade de semeadura. In: SIMPÓSIO SOBRE CULTURA DA SOJA NOS CERRADOS, 1992, Uberaba. Anais. Piracicaba : Potafos, 1993. p.267-298. 